\title{
The Influencing Factors on Unemployment Level - The Case of Albania
}

\author{
Eleni Vangjeli \\ Jorida Agolli \\ University “Fan S.Noli” Korce, Albania, Faculty of Economy, Department of Finance
}

\begin{abstract}
Research background: The empirical studies in labor market indicated that there are many factors that affect unemployment. These studies have analyzed these factors and concluded that exist a mutual relationship between them and unemployment. The relation between employment and FDI were studied by Craigwell (2006) and Karlsson et al. (2009). The effects of minimal wage on employment were studied by Katz and Kruger (1992) and Card (1992a) as well as Stephen Machin and Alan Manning (1994). Card, D. and Krueger, B. (1994) analyzed the effects of minimum wage raise, on fast-food restaurants in New Jersey and Pennsylvania. On the other hand, Neumark and Wascher (2000) in their findings explained that raising the minimal wage by $10 \%$ reduced the teenager employment rate with $1-2 \%$ and brought the reduction of total employment by $1.5-2 \%$. Meanwhile, Grossberg and Sicilian (2004), found mixed results in their estimations of the minimal wage effects on employment duration period. Krugman, $\mathrm{P}(2015)$ one of the economy nobelist defends the theory of raising the minimal wage as a condition for improving the wellbeing. W. Phillips, (1958) studied a negative inverse relation between unemployment and inflation. Barro (1995), De Gregorio (1994), Bruno (1994) concluded that low inflation is accompanied by economic growth and higher employment level. Purpose of the article: The main aim of this article is to study and analyse factors affecting unemployment levels, because the unemployment is a critical problem in our country. We have analyzed the mutual effect of selected factors on unemployment level. The selected factors are FDI, domestic investments, inflation and minimal wage. Methodology/methods: To calculate the impact of this factors on the unemploymentlevel was used time series data for the period 1995 - 2013. Relying on time series data was made regression analysis using SPPS-21 program. Findings: Based on the testing results, we conclude that FDI, domestic investments and inflation affect negatively the unemployment level and this effect is statistically important, whereas the minimal wage has a low positive effect but such effect is not important.
\end{abstract}

Keywords: unemployment; FDI; domestic investments; inflation; minimal wage.

JEL Classification: J00

\section{Introduction \\ Purpose of the Article}

Before 90s, the structural economic orientation toward agricultural products and light and heavy industry, lying in every corner of the country, made possible the achievement of complete employment in both rural and urban areas.

After the 90 s, as a result of the macroeconomic reforms and the restructuring economy, like all other countries in economic transition, Albania experienced a decrease of the participating rate to the labour force. This decrease for the period 19952005 was in the mass of $17.8 \%$ (from $71.9 \%$ in 1995 to $54.1 \%$ in 2005) 1 . The fall continued for 2006 in the amount of $0.4 \%$, followed by a significant rise in 2007 at the rate $13.6 \%$, compared to the previous year. The lowest levels were registered after 2000 , where less than $2 / 3$ of the working age population were active in the labour market. The year 2008 was followed by a decrease in labour force participation from $65 \%$ in 2007 to $61 \%$. Then the fall continued year after year, reaching the level of $59 \%$ in 2013 . The purpose of this article is to study and analyse factors affecting unemployment levels.

\footnotetext{
1 Statistical Year Books 1995- 2005
} 
Unemployment is a critical problem in our country. For this reason, the study of this indicator is a problem that needs to be solved. Indicator statistics over years support this conclusion. According to statistics, the unemployment in 90 increased rapidly.

In the end of 1995 the unemployment rate was $13 \%$. During the 1997, due to the damages that labour market suffered, the unemployment rate increased again at the level of $14.9 \%$. Afterward, in the coming period (1999-2008), unemployment values were decreased. According to the statistics, the unemployment rate was $13.2 \%$ in 2008 . Unemployment has undergone an upward trend since 2009, with 13.8\%, followed by $14.2 \%$ in 2010 .

In the coming year, unemployment suffered a slight increase with $0.1 \%$, going up to $14.3 \%$.

While for the 2013, the unemployment rate was $16.1 \%$, which remained in evaluation terms. (see Appendix, graph.1)

\section{Literature Background}

The empirical studies in labor market showed that there are many factors that affect unemployment. These studies have analyzed these factors and concluded that exist a mutual relationship between them and unemployment. Some of the factors that these studies have analyzed are inflation, FDI, investments and minimal wage.

Previous empirical studies that we are presenting, show that net investments expand production activities in economy, affecting positively the increase of production and consequently the employment.

In other words, production oriented investments generate vacancies directly in the area where investments have been done and indirectly other areas related to the investments. Also, investments in production sectors where labor is a dominant factor have an important quantitative effect on employment, related to creating new jobs and reducing the unemployment level.

Researchers Stephen Bond and John V. Reenen (2007) in their study made econometric researches about the relationship of investments and changes of demand for designer brands based on the analysis of individual domestic companies and multinational companies. They pointed out the importance in multinational companies' growth by concluding that: "Multinational corporations are a considerable part of domestic investments and employment in many countries";

Bande, R. and Karranasou, M. (2010) in their study assessed the regional unemployment in Spain related to the stock capital during 1980-2000. Their empirical findings showed that capital accumulation is a determining force for the unemployment level showing that there exist a negative relation between the capital accumulation and the regional unemployment level.

In the event of foreign direct investments (FDI), the economic and social effects are also depending on investors' motivation and the business strategy where it is invested.

The analysis of FDI attracted to economy, mainly the aspect of their volume and foreign investors' motivation is also important in determining the effects of FDI on employment. Craigwell (2006) studied the relation between employment and FDI for the period 1990-2000 for 20 countries that speak English and German in the Caribbean countries. The conclusion was that FDI increase is accompanied with employment in these countries. The same conclusion reached Karlsson et al. (2009). They tested the relationship between FDI and employment in the production sector in China for the period 19982004 concluding that FDI have a positive impact on the employment level. Also, their achievements show that FDI have a positive indirect impact on the employment level for the Chinese domestic private companies.

There are empirical studies that are mainly focused on treating the minimal wage effect on employment. Data show that minimal wage effects on employment are very sensitive to small changes in specifying the empirical model.

Katz and Kruger (1992) and Card (1992a) in their analysis of minimal wage effects on employment for the period 1990 1991 and the early study on minimal wage in California - Card (1992b) showed that raising of the minimal wage does not affect negatively the employment.

Stephen Machin and Alan Manning (1994) as well in their study about minimal wage effects in Great Britain reached the same conclusion. 
Card, D. and Krueger, B. (1994) looked at the effects on fast-food restaurants in New Jersey and Pennsylvania of raising the minimum wage in 1992. In their study, they found out that raising of minimal wage has no effect or an unimportant positive one on employment. On the other hand,Neumark and Wascher (2000) with their findings showed that raising the minimal wage by $10 \%$ reduced by $1-2 \%$ the employment of the teenagers and another reduction by $1.5-2 \%$ in employing the young adults. Meanwhile, Grossberg and Sicilian (2004), found mixed results in their estimations of the minimal wage effects on employment duration period. Their findings suggest that an increase of the minimal wages for people with low wages reduces the movements (circulation in the labor market). On the other hand, increases of the minimal wage for those people who have high salaries are related positively with the circulation increase.

Krugman, $\mathrm{P}(2015)$ one of the economy's nobelists defends the theory of raising the minimal wage as a condition for improving the wellbeing. He argues that today's workforce is being more qualitative and productive therefore the increase of wage will have petty effects on the unemployment levels but large ones on employees' incomes.

In analyzing differently studies related to minimal wage effects on employment, Neumark and Wascher (2007) divide these studies into two groups: studies that have a positive effect on employment are those studies that focus on wider groups where the competitive model predicts decreasing effects on employment. Secondly, there are studies which are focused on least-skilled groups by showing a decrease of employment for these groups.

W. Phillips, (1958) found out an inverse relation between unemployment and inflation. The course of his basic ideas is as follows: the more people work, the more the national production will grow, giving higher wages. Therefore, the consumers will have more money and will spend more asking for more goods and services and as result affecting the process of goods and services as well. In other words, Phillips demonstrated that unemployment and inflation have a reciprocal relation: if inflation goes up, unemployment goes down, and if inflation goes down, unemployment goes up.

Meanwhile the Phillips curb is theoretically useful, practically it is less useful. The reciprocal relation exists only during the short-term period. The reciprocal relation exists only during the short-term period. In a long-term period, unemployment always turns into its natural form by zeroing the cyclic unemployment and equal inflation with expected inflation.

In the end of the 80 s, academic and professional thinking supports the idea that low inflation is accompanied by economic growth and higher employment level. "(Barro1995, De Gregorio 1994, Bruno 1994)1. Such a conclusion is in objection with the theoretical analysis as discussed earlier here.

In the meantime, Karanassou, M. et.al. (2010), in their study brought a new evidence in the long-term relationship between inflation and unemployment. According to them, the inclination of US Phillips curve is not vertical in the long-term period therefore the policy makers must consider classical dichotomy thesis.

\section{Theoretical Framework}

In our paper, we have analyzed the influencing factors on unemployment levels. Referring to the conditions in our own country, we think that the factors which affected the unemployment levels are:
a. Inflation rate (INF)
b. Domnestic Investment (DI/GDP)
c. Foreign Direct Investment (FDI/GDP)
d. Minimum wage rate (WM)

Let us analyze theoretically each of the these factors.

Unemployment is an important macro-economic indicator of a country. Unemployment is a labor market indicator. It also is an apparent indicator if the living standards in a country. It is closely related to economic growth. When a country keeps its employees employed longer, it reaches a higher GDP level. In the current study, unemployment level is chosen to be a

\footnotetext{
1 -Barro, J. R. (1995), "Inflation and Economic Growth" NBER Working Paper Nr. 5326

-Bruno, M. and Easterly, W. (1994), "Inflation and Growth: In Search of a Stable Relationship"

-De Gregorio, J (1994) "Haw does the Foreign Direct Investment Affect The Economic Growth " NBER Working Paper Nr 5057
} 
dependent variable. Inflation is a macroeconomic indicator that shows the change in the average level of prices in a country. Inflation shows the alternations in living costs. In other words, inflation shows how much need the income to increase in order to maintain an unchanging living standard.

Inflation could not be eliminated without increasing unemployment for at least a given period of time and unemployment could not be reduced without risking the inflation increase. This is the basic inverse relation and the problem of stability policy.

Domestic investment is that part of national production which goes for creating capitals (buildings, equipments and public assets such as roads) and is considered to be an important determiner of the economic growth affecting positively the reduction of unemployment level.

FDI and domestic investments as well are also important indicators affecting the unemployment level. In the case of Foreign Direct Investments (FDI), the economic and social effects also depend on the motivation of investors and the investing business strategy. The higher FDI, the lower the unemployment level.

Minimum wage is part of the labor cost. Labor costs represent the main component of the total costs. The guiding principle is that a company will supply a product whose price will cover at least its costs. Prices increase as costs increase. If we get closer to full employment levels, prices increase as the products increase. This is an image of adaption with the labor market, where higher employment levels increase the wages. There are two impacts affecting employment: replacing impact where increase of wages increase the employment; and income impact which gives the opposite effect, thus, increase of wages reduces employment, and unemployment levels go up.

In our study, inflation, domestic investments, FDI and minimum wage are selected as independent variables

\section{Research Methodology}

\subsection{Test of normality}

Before we create the model, we have tested the depended variable if it has normal spread. Below we have represented the results of the test.

Table no. 1 Tests of Normality

\begin{tabular}{|l|l|l|l|l|l|l|}
\hline \multicolumn{3}{|l|}{ Kolmogorov-Smirnova } & \multicolumn{3}{l|}{ Shapiro-Wilk } \\
\cline { 2 - 7 } & Statistic & df & Sig. & Statistic & df & Sig. \\
\hline Unemployment & 174 & 18 & .155 & .912 & 18 & .095 \\
\hline
\end{tabular}

Since the coefficient of testsignificance, Kolmogorov-Smirnova is 0.155 and coefficient of test significance Shapiro-Wilk is 0.095 , so are higher values than 0.05 , then the dependent variable (unemployment level) has a normal distribution. Based on this result, we will use the multiple linear regression model in order to determine the effect of selected factors on unemployment level.

\subsection{Model Specification}

The functional appearance of the model will be:

$U N=f($ INF, DI/GDP, FDI/GDP,WM)

Linear equation that expresses the relationship between the explanatory variables has the form:

$U N=\beta_{0}+\beta_{1} I N F+\beta_{2} D I / G D P+\beta_{3} F D I / G D P+\beta_{4} M W+\mu_{t}$

Expected signs of variables is:

$\beta_{1}, \beta_{2}, \beta_{3}, \beta_{4},<0$ 
Table no. 2 Variables Description

\begin{tabular}{|l|l|l|l|}
\hline Variables & Priori hypothesis & Definition & Units \\
\hline Inflation & Negative sign & Indicator of economic development of the country & $\%$ \\
\hline $\begin{array}{l}\text { Domestic Investment / } \\
\text { GDP }\end{array}$ & Negative sign & Indicator of economic development of the country & $\%$ \\
\hline $\begin{array}{l}\text { Foreign Direct Investment/ } \\
\text { GDP }\end{array}$ & Negative sign & Indicator of current transfers & $\%$ \\
\hline Rate of minimum Wage & $\begin{array}{l}\text { Positive/ Negative } \\
\text { sign }\end{array}$ & Indicator of labour trade & $\%$ \\
\hline
\end{tabular}

For all the variables have the same measurement unit (\%), the variables DI and FDI are estimated as compared to GDP.

\subsection{Hypothesis}

This research is based on the following hypothesis which will be tested for above mentioned regression model.

$H_{0}$ : Inflation, Domestic Investment, FDI, Minimum wage have not any effect on unemployment level

$\mathrm{H}_{1}$ : Inflation, Domestic Investment, FDI, Minimum wage have effect on unemployment level

\subsection{Empirical Results}

To calculate the impact of the variables on the level of unemployment was used time series data for the period 1995 2013. Relying on time series data was made regression analysis using SPPS-21 program. The test results are shown in the table below:

Table no.3 Summary of multiple regression results

\begin{tabular}{|l|l|l|}
\hline Variables & Coefficient $\beta$ & Significance \\
\hline INF & -.090 & .049 \\
\hline DI/GDP & -.141 & .014 \\
\hline FDI/GDP & -.603 & .000 \\
\hline MW & .002 & .959 \\
\hline
\end{tabular}

$\mathrm{UN}=22.605-0.090 \mathrm{INF}-0.141 \mathrm{DI} / \mathrm{GDP}-0.603 \mathrm{FDI} / \mathrm{GDP}+0.002 \mathrm{MW}+\mu_{\mathrm{t}}$

The testing results show that there is a strong linear relation between independent variables and the dependent one in the model $R=0.855$ (see appendix: Regression 1).

The model has explanatory power which is relatively high: $R^{2}=0.642$. Through $F$ test, we can see the importance of the model. Since sig. $=0.002<0.05$ the independent variables in the model explain the dependent variable. This means that the hypothesis $\left(\mathrm{H}_{0}\right)$ which argues that all independent variables have no effect on dependent variable is turned down, confirming thus the hypothesis $\mathrm{H}_{1}$ of the study. AS a conclusion, independent variables affect the dependent variable. The effect of variables INF, DI/GDP and FDI/GDP is negative which means that if these variables will increase, unemployment will be reduced. According the regression equation we see that variables DI/GDP and FDI/GDP have greater effects. Meanwhile, minimal wage effect is positive showing that if minimal wage level goes up, unemployment level goes up too, but according the regression equation, such effect is relatively inconsiderable.

On the other hand, variable of minimal wage even though has little effect on unemployment level, it is statistically unimportant (sig. $=0.959)$. A reason why we think it could have affected the result could be the correlation between independent variables. Proceeding with the analysis, we tested the correlation between independent variables. (See the table of results in the appendix). The minimal wage turns out to have a strong correlation with DI/GDP and this correlation 
is statistically important. In order to avoid the correlation for confirming the above results, we replaced the variable of minimal wage by introducing to the model another representing variable: average wage. The testing results are shown on table no.4

Table no.4 Summary of multiple regression results

\begin{tabular}{|l|l|l|}
\hline Variables & Coefficient $\beta$ & Significance \\
\hline INF & -0.081 & 0.036 \\
\hline DI/GDP & -0.112 & 0.021 \\
\hline FDI/GDP & -0.406 & 0.008 \\
\hline AW & 0.136 & 0.038 \\
\hline
\end{tabular}

$\mathrm{UN}=19.055-0.081 \mathrm{INF}-0.112 \mathrm{DI} / \mathrm{GDP}-0.406 \mathrm{FDI} / \mathrm{GDP}+0.136 \mathrm{MW}+\mu_{\mathrm{t}}$

From the results we see that the effect of all variables on unemployment level is statistically important. The model has high explanatory power $R^{2}=0.753$ and sig. $=0.000^{\mathrm{b}}$.(See appendix: Regression 2 ). The effect of variables INF, DI/GDP and FDI/GDP is negative as in the previous testing (Table no.4). Whereas the average wage effect is a positive effect (it has the same tendency as the minimal wage) and statistically important, showing therefore the effect of incomes on unemployment level. Therefore, the results of our study match the previous empirical studies about the labor market by proving that FDI are an important factor in increasing employment, whereas the increase of minimal wage has an insignificant effect on today's labor markets.

\section{Summary and Conclusions}

Unemployment is a major problem for a specific country for as long as it is constant in high levels. In our country, high unemployment levels appeared after the $90 \mathrm{~s}$ as a result of massive privatizations of underproductive state enterprises. Since that period, unemployment is present undergoing variations in different periods of time by $13-16 \%$. Change in time of unemployment level came as result of effects of several factors. We have been analyzing the effect of some factors we think have affected the unemployment levels. These factors are: domestic investments, FDI, inflation and minimal wage. Empirical analysis showed that these factors affect the unemployment levels. Domestic investments, FDI, inflation affect negatively and are statistically important which means that if these indicators go up, unemployment levels go down, whereas minimal wage has positively low effects. From this point of view, one should not aim the increase of the minimal wage since it would worsen the employment level by increasing unemployment. These results agree with other previous empirical studies. Of the above mentioned factors, it is domestic investments and FDI which have greater effects on unemployment levels. Based on these results, we would recommend stimulation of domestic investments and FDI as factors which improve the economic situation in the country increasing employment and economic growth further. In order to stimulate FDI, among other factors such as political stability, interest rates, etc, policy makers should improve the fiscal package by reducing those taxes which are higher as compared with the rest of the Region in order to make our county a competitive one.

\section{References}

[1] Barro, J. R. (1995), "Inflation and Economic Growth" NBER Working Paper Nr. 5326

[2] Bruno, M. and Easterly, W. (1994), "Inflation and Growth: In Search of a Stable Relationship"

[3] De Gregorio, J (1994) "Haw does the Foreign Direct Investment Affect The Economic Growth "

[4] NBER Working Paper $\mathrm{Nr} 5057$.

[5] Bond, S. and Reenen, John, V. and Bloom, N (2007) "Uncertainty and Investment Dynamics" IDEAS Journals. p. 321.

[6] Karanassou, M. and Sala,H.(2010) "The US inflation - Unemployment trade off revisited: New evidence

[7] for policy making" Journal of Policy Modeling, 32, 758777.

[8] Karanassou, M., Sala, H., and D. J. Snower (2010), "Phillips Curves and Unemployment Dynamics: A Critiqueand a Holistic Perspective" Journal of Economic Surveys, 24, 151.

[9] Karanassou, M. and Bande, R., (2013),"Spanish Regional Unemployment Revisited: 
[10]The Role of Capital Accumulation, Regional Studies", DOI: 10.1080/00343404. 2013.779657

[11] Krugman, P (2015) "Liberals and Wages" New York Time, 4 July 2015.

[12] Karlsson, S et al.(2009) "Foreign Firms and Chinese Employment" World Economy, 32(1)178201.

[13] Katz,L.F \&Krueger, Alan, B.(1992) "The effect of the minimum wage on the fastfood industry,"

[14] Industrial and Labor Relations Review, ILR Review, Cornell University, ILR School, vol.46(1), pages

[15] 621, October.

[16] Neumark, D and Wascher, W (2000) "Employment effects of minimum and subminimum wage: panel data on state minimum wage laws" Industrial and labor relations review.

[17] Neumark, D and Wascher, W (2007) "Minimum wages and unemployment" IZA DP 2570 January 2007

[18] Machin, S and Manning, A (1994) "The Effects of Minimum Wages on Employment: Theory and Evidence from Britain", JLE, Vol. 17, no. 1 (January 1999): 122.

[19] Card, D and Kruger, A. (1994) "Minimum wage and employment": A case study of the fast food industry in New Jersey and Pennsylvania The American Economic Review volume 84 Issue 4 September 1994 (772793)

[20] Craigwell, R (2006) "Foreign Direct Investment and unemployment in the English and DutchSpeaking Caribbean" Working papers, Tripartite Caribbean Employment Forum 2006, Barbados.

[21] Griffith, R and Kimberly, W(2008) "The significance of foreign Direct Investment to Caribbean Development"

[22] Grossberg, A and Sicilian, P (2004), "Legal Minimum Wages and Employment Duration"

[23] Southern Economic Journal, Southern Economic Association, vol. 70(3) pages 631645 January

[24] Phillips,W (1958) "The relation between unemployment and the rate of change of money wage

[25] rates in united Kingdom 18611957" Economic, 25(100) 283299

\section{Appendix}

\section{List of tables}

Table No.1 Tests of Normality

\begin{tabular}{|l|l|l|l|l|l|l|}
\hline \multicolumn{3}{|l|}{ Kolmogorov-Smirnova } & \multicolumn{3}{l|}{ Shapiro-Wilk } \\
\cline { 2 - 7 } & Statistic & df & Sig. & Statistic & df & Sig. \\
\hline Unemployment & .174 & 18 & .155 & .912 & 18 & .095 \\
\hline
\end{tabular}

a. Lilliefors Significance Correction

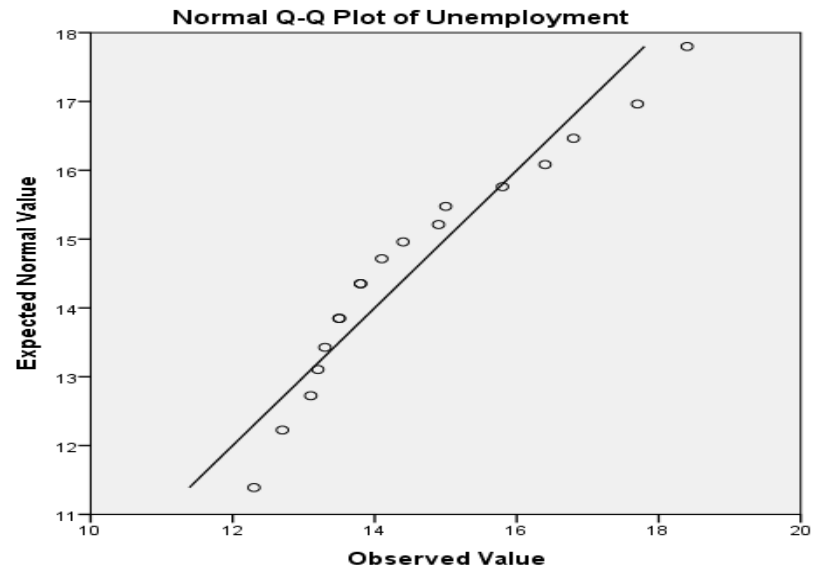




\section{Regression 1}

Model Summary

\begin{tabular}{|l|l|l|l|l|}
\hline Model & $\mathrm{R}$ & R Square & Adjusted R Square & $\begin{array}{l}\text { Std. Error of the } \\
\text { Estimate }\end{array}$ \\
\hline 1 & $.855^{\mathrm{a}}$ & .732 & .642 & 1.02584 \\
\hline
\end{tabular}

a. Predictors: (Constant), MW, Inv/GDP, FDI/GDP, Inflation

ANOVAa

\begin{tabular}{|ll|l|l|l|l|l|}
\hline Model & & Sum of Squares & df & Mean Square & F & Sig. \\
\hline \multirow{3}{*}{1} & Regression & 34.407 & 4 & 8.602 & 8.174 & $.002^{\mathrm{b}}$ \\
& Residual & 12.628 & 12 & 1.052 & & \\
& Total & 47.035 & 16 & & & \\
\hline
\end{tabular}

a. Dependent Variable: Unemployment

b. Predictors: (Constant),MW, Inv/GDP, FDI/GDP, Inflation

Coefficientsa

\begin{tabular}{|l|l|l|l|l|l|}
\hline \multirow{2}{*}{} & \multicolumn{2}{|l|}{ Unstandardized Coefficients } & \multicolumn{2}{|l|}{$\begin{array}{l}\text { Standardized } \\
\text { Coefficients }\end{array}$} & \multirow{2}{*}{ Sig. } \\
\cline { 2 - 4 } & $B$ & Std. Error & Beta & \\
\hline (Constant) & 22.605 & 2.101 & & 10.759 & .000 \\
FDI/GDP & .603 & .128 & -.887 & -4.731 & .000 \\
DI/GDP &. .141 & .049 & -.536 & -2.873 & .014 \\
Inflation & .090 & .041 & -.449 & -2.190 & .049 \\
MW & .002 & .040 & .009 & .052 & .959 \\
\hline
\end{tabular}

a. Dependent Variable: Unemployment

\section{Regression 2}

Variables Entered/Removeda

\begin{tabular}{|l|l|l|l|}
\hline Model & Variables Entered & Variables Removed & Method \\
\hline 1 & $\begin{array}{l}\text { AW, Inv/GDP, Inflation, } \\
\text { FDI/GDPb }\end{array}$ & & Enter \\
\hline
\end{tabular}

a. Dependent Variable: Unemployment

b. All requested variables entered.

Model Summary 


\begin{tabular}{|l|l|l|l|l|}
\hline Model & R & R Square & Adjusted R Square & $\begin{array}{l}\text { Std. Error of the } \\
\text { Estimate }\end{array}$ \\
\hline 1 & $.903^{\mathrm{a}}$ & .815 & .753 & .85145 \\
\hline
\end{tabular}

a. Predictors: (Constant), AW, Inv/GDP, Inflation, FDI/GDP

ANOVAa

\begin{tabular}{|ll|l|l|l|l|l|}
\hline Model & & Sum of Squares & df & Mean Square & F & Sig. \\
\hline & Regression & 38.336 & 4 & 9.584 & 13.220 & $.000^{\mathrm{b}}$ \\
& Residual & 8.700 & 12 & .725 & & \\
& Total & 47.035 & 16 & & & \\
\hline
\end{tabular}

a. Dependent Variable: Unemployment

b. Predictors: (Constant), AW, Inv/GDP, Inflation, FDI/GDP

Coefficientsa

\begin{tabular}{|c|c|c|c|c|c|}
\hline \multirow[t]{2}{*}{ Model } & \multicolumn{2}{|c|}{ Unstandardized Coefficients } & \multirow{2}{*}{\begin{tabular}{|l}
$\begin{array}{l}\text { Standardized } \\
\text { Coefficients }\end{array}$ \\
Beta
\end{tabular}} & t & \multirow[t]{2}{*}{ Sig. } \\
\hline & $B$ & Std. Error & & & \\
\hline (Constant) & 19.055 & 2.227 & & 8.558 & .000 \\
\hline Inflation & -.081 & .034 & .402 & -2.367 & .036 \\
\hline Inv/GDP & -112 & .042 & .428 & -2.655 & .021 \\
\hline FDI/GDP & -.406 & 128 & -597 & -3.159 & .008 \\
\hline AW & .136 & .058 & .413 & 2.329 & .038 \\
\hline
\end{tabular}

a. Dependent Variable: Unemployment

\section{Correlations}

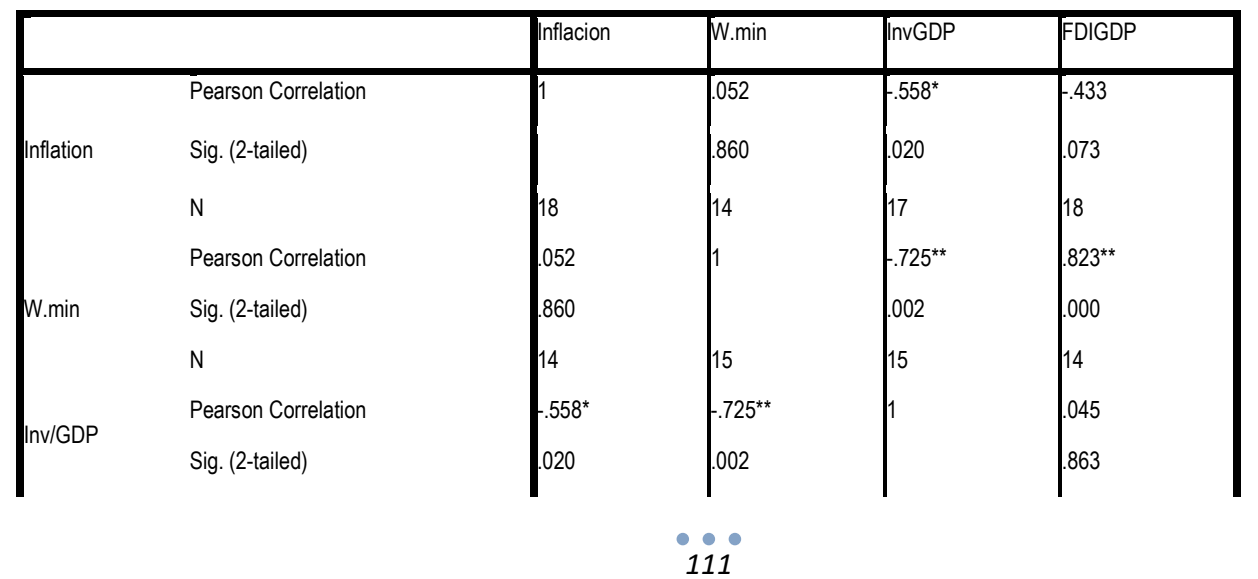




\begin{tabular}{|c|c|c|c|c|c|}
\hline & $\mathrm{N}$ & 17 & |15 & 18 & |17 \\
\hline & Pearson Correlation & -.433 & $.823^{* \star}$ & .045 & 1 \\
\hline$=D I / G D P$ & Sig. (2-tailed) & .073 & .000 & .863 & \\
\hline & $\mathrm{N}$ & 18 & 14 & 17 & 18 \\
\hline
\end{tabular}

*. Correlation is significant at the 0.05 level (2-tailed).

**. Correlation is significant at the 0.01 level (2-tailed).

Graph.1 The level of unymployment during the years, Source: INSTAT 1996-2013

The Level of unemployment

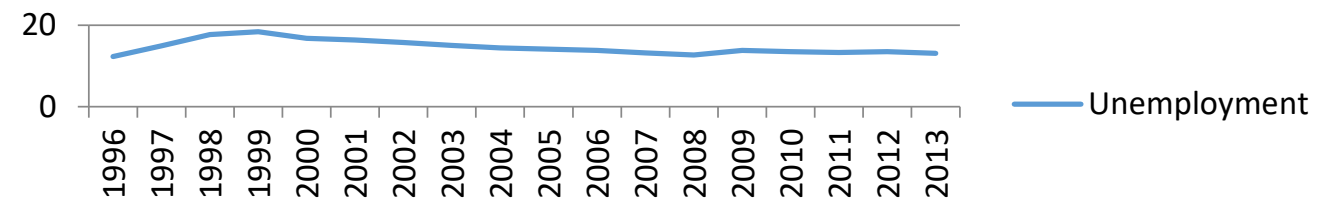

